JEL F02

\title{
METHODOLOGICAL FOUNDATIONS OF ORGANIZATIONAL AND ECONOMIC CONCEPT FORMATION OF ENERGY SAVING
}

\author{
Volodymyr Byba*, PhD (Technical Sciences), Assoc. Professor \\ Inna Miniailenko**, PhD (Economics), Assoc. Professor \\ National University "Yuri Kondratyuk Poltava Polytechnic"
}

* ORCID 0000-0002-0949-206X

(C)Byba V., 2021.

(C)Miniailenko I., 2021.

Стаття отримана редакиією 04.01.2021 p.

The article was received by editorial board on 04.01.2021

Introduction. The rapid development of market relations and the influence of many factors on the activities of the enterprise, the irrational use of energy resources is one of the important factors to which attention should be paid. One of the components of enterprise reform is the introduction of energy-saving technologies in accordance with world standards. This is what prompts the study of the energy management process at the enterprise, which affects the increase of profitability of the enterprise and the improvement of the population living conditions. The introduction of energy saving at the enterprise should be accompanied by consideration of the problem of organizing the process, which should be considered comprehensively.

Analysis of recent research sources and publications. Let's analyze the essence of the concept of organizational and economic concept of energy saving, but there is no single scientific definition of this term. The most common interpretations of the concept of organizational and economic concept studied leading scientists, namely: P.D. Nemish, I.D. Mykhailenko, T.M. Afonchenko, V.V. Bevz, K.I. Dokunin, T.V. Serdiuk, V.V. Dzhedzhula, Yu.I. Chystov, Yu. Vovk, I.Ya. Ippolitov et al. [1-15].

Nemish P.D. [10] considers the concept of energy saving as a set of measures that will increase energy potential by saving energy costs, but it is advisable to take into account the available untapped opportunities. Although Mikhailenko I.D. [9] noted that the maximum use of energy potential at minimum energy costs forms the conceptual basis of energy saving, but the key element should be identified management levers of influence on the main elements.

Bevz I.V. [2] noted that organizational and economic levers contribute to the strengthening of energy potential. Dokukina K.I. holds the same opinion [5], which emphasizes the interaction of legal, organizational, managerial, economic and technical elements of this concept.

The key role of the innovation component is indicated by the definition of Serdiuk T.V. [13]. And Dzhedzhula V.V. [4] emphasized the implementation of those energy-saving measures that reduce the environmental impact on the environment.

It is necessary to agree with Chystov Yu.I. [14] that the energy saving process is carried out due to an efficient system of tools.

Vovk Yu. [3] approach to the interpretation of the concept of energy saving as a complex management system is interesting.

Shivakumar A., Kypriianov I. investigated the features of energy policy formation in different countries, which were taken into account in this study $[8,15]$.

Background. The purpose of this study is to form an organizational and economic concept of energy saving in the enterprise, the implementation of which will increase the efficiency of economic activity, reduce the environmental impact on the environment and strengthen the competitiveness of business.

The main tasks are: generalization of the concept of «organizational and economic concept of energy saving», definition of its key elements, principles of effective implementation in practice, formation of criteria and stages of implementation, methods of stimulating energy saving. 
Results. The essence of the problem of energy saving organizational and economic concept has been researched by native and foreign scientists. However, a clearly defined definition of the concept of «organizational and economic concept» has not yet been formed.

In the course of the research the own interpretation of the organizational and economic concept was developed, which in its composition combines organizational and economic goals, impulses and management decisions aimed at achieving the set goals and objectives, methods of use.

Table 1 formulates approaches to defining the essence of the concept of organizational and economic concept of energy saving.

Approaches to defining the essence of the concept of «organizational and

Table 1 economic concept of energy saving»

\begin{tabular}{|c|c|}
\hline Authors & The essence of the concept of «Organizational and economic concept» \\
\hline P.D. Nemish [10] & $\begin{array}{l}\text { The economic concept of energy saving is a set of measures that ensure the } \\
\text { most efficient use of energy potential with minimal specific energy } \\
\text { consumption per unit of output. It should have a pronounced stimulating } \\
\text { character, using the savings achieved as a result of improving the energy } \\
\text { efficiency of production. }\end{array}$ \\
\hline $\begin{array}{l}\text { I.D. Mykhailenko, } \\
\text { T.M. Afonchenkova [9] }\end{array}$ & $\begin{array}{l}\text { This is a set of measures that ensures maximum use of energy potential with } \\
\text { minimum specific energy costs per unit of production }\end{array}$ \\
\hline I.V. Bevz [2] & $\begin{array}{l}\text { It is a set of organizational and economic levers (each of which has its own } \\
\text { forms of management influence), which affect the economic and } \\
\text { organizational parameters of the enterprise, which contributes to the formation } \\
\text { and strengthening of energy potential, obtaining competitive efficiency and } \\
\text { competitiveness. }\end{array}$ \\
\hline K.I. Dokunina [5] & $\begin{array}{l}\text { The structure of the concept of energy saving provides for legal, } \\
\text { organizational, managerial, economic and technical aspects, the interaction of } \\
\text { which in the end should have a positive economic result. }\end{array}$ \\
\hline T.V. Serdiuk [13] & $\begin{array}{l}\text { The system of interconnected economic and organizational elements aimed at } \\
\text { activating the economical consumption of energy resources, the introduction of } \\
\text { energy-saving measures, taking into account innovative achievements in the } \\
\text { field, both technological and product }\end{array}$ \\
\hline V.V. Dzhedzhula [4] & $\begin{array}{l}\text { Organizational and economic concept of energy saving of industrial } \\
\text { enterprises is a set of economic, organizational, motivational methods and } \\
\text { techniques aimed at cost-effective detection and maximum use of energy } \\
\text { saving potential in order to minimize the specific costs of production and } \\
\text { reduce the environmental impact on the environment. }\end{array}$ \\
\hline Yu.I. Chystov [14] & $\begin{array}{l}\text { A system of tools, which for a certain application is activated and carries out } \\
\text { the process of energy saving, due to which it should have a positive effect of } \\
\text { reflection in several planes, which reflects the multi-vector nature of the } \\
\text { mechanism }\end{array}$ \\
\hline Yu. Vovk [3] & $\begin{array}{l}\text { A comprehensive management system, characterized by the rational use of } \\
\text { resources in the enterprise, which can be used to achieve management goals } \\
\text { through economic methods }\end{array}$ \\
\hline I. Ya. Ippolitova [7] & $\begin{array}{l}\text { Combination and integration of organizational and economic goals, incentives } \\
\text { and management actions aimed at energy saving with the help of management } \\
\text { methods and tools, carried out by influencing the subject on the object of } \\
\text { energy saving in order to reduce energy dependence and increase efficiency } \\
\text { perspective }\end{array}$ \\
\hline
\end{tabular}

Source: developed by the authors on the basis of $[2-5,7,9,10,13]$

As a result of generalization, it is expedient to reveal the essence of this concept as follows: «Organizational and economic concept of energy saving is a combination and implementation of organizational and economic goals, impulses and management actions aimed at reducing energy consumption and energy consumption, the use of which will increase profitability, competitiveness and efficiency of innovative technologies at the enterprise». 
Energy saving is one of the components of energy management, as its practical side, as it involves the use of advanced technologies and equipment. After analyzing scientific sources, the main contradiction in the interpretation of the term «energy saving» is the definition of its objects. As an object of energy saving, V. Zhovtianskyi [11, 12] describes, that this is the saving of different types of fuel and energy resources. According to the EU directive, the object of energy saving is energy saving.

According to the Law of Ukraine "On Energy Conservation" of 1994, the object is the rational use and economical consumption of primary and transformed energy and natural energy resources. According to the recommendations of the International Energy Agency (IEA), the object of energy saving is the efficiency of energy demand management. All this can be considered as a process of forming the organizational and economic concept of energy saving at the enterprise [12].

Creating an effective organizational and economic concept of energy saving is a very important issue in a market economy, because its solution can ensure the rational use of energy in enterprises. The main purpose of the mechanism is to reduce energy dependence on the generating company using scientifically sound methods and tools at all levels of economic activity of the enterprise.

The tasks of the organizational and economic concept of energy saving are:

- creation of restrictions on irrational use of energy resources in technical, economic, production and organizational divisions of the enterprise.

- motivation and encouragement of employees of the enterprise to save and preserve energy resources, natural resources;

- economic substantiation of introduction of energy saving measures at the enterprise;

- monitoring the implementation of energy saving measures.

The implementation of the concept of energy saving in the production sphere requires the improvement of the existing organizational and economic concept through the application of a set of measures. The energy saving mechanism has a significant number of components, so the consistency of their work and the successful implementation of energy saving policy depend on the quality of all its components.

In order to effectively implement the organizational and economic concept of energy saving in the economic activity of the enterprise, principles should be formed, which can be considered in Figure 1.

When reorganizing production, it is necessary to take into account changes in the cost of energy consumed and production volumes by adjusting management decisions. The introduction of the organizational and economic concept of energy saving in the economic activity of the enterprise should be carried out gradually and in stages.

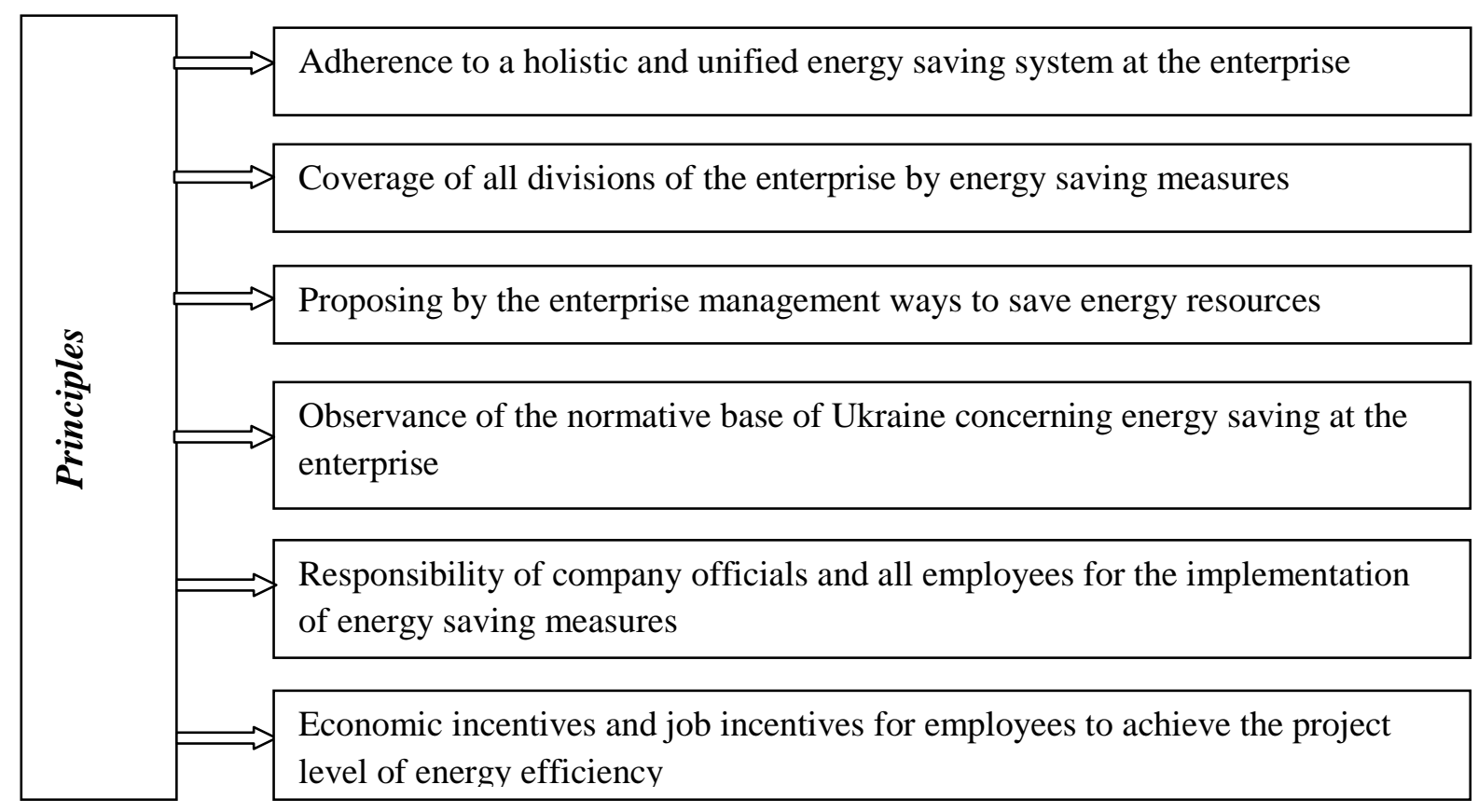

Fig. 1. Principles of organizational and economic mechanism of energy saving Source: developed by the authors on the basis of [9-11]

Thus, it is possible to form a certain chronology of the implementation of these stages in the activities of the enterprise, namely: 
- the first stage - formation and selection of a group of energy managers who will develop and maintain energy saving measures at the enterprise;

- the second stage - the creation of an appropriate group of persons who will control the use of funds allocated from the energy saving fund;

- the third stage - direct coverage of the process of development and implementation of the mechanism in production;

- the fourth stage - implementation of energy saving measures;

- the fifth stage is the process of adjustment and improvement of the organizational and economic concept.

The effectiveness of the implementation of organizational and economic measures for energy saving can be analyzed and evaluated using the established criteria, which are presented in Figure 2.

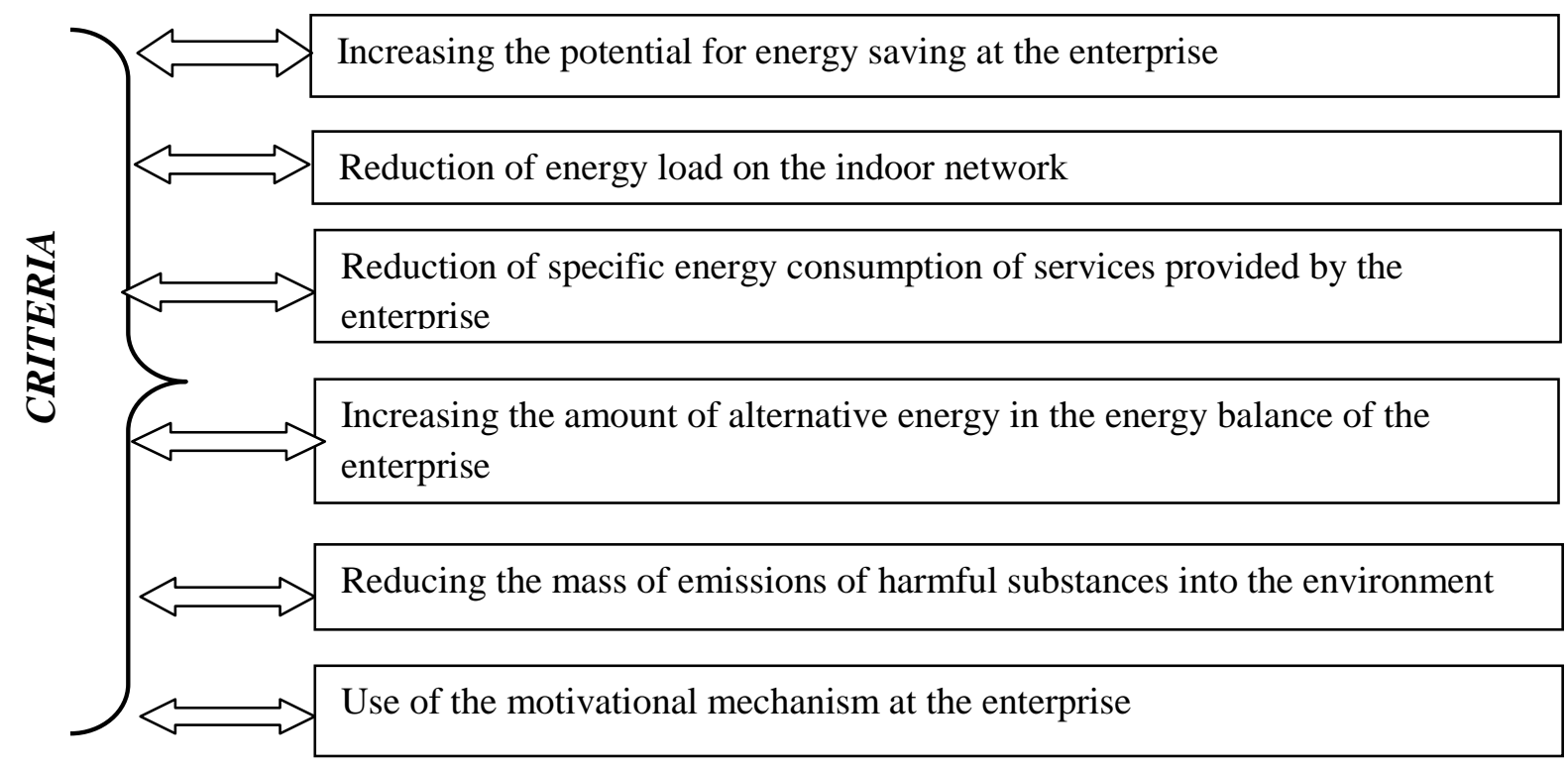

Fig. 2. Criteria for evaluating the effectiveness of organizational and economic energy saving

Source: developed on the basis of [10,13]

The implementation of energy saving should be carried out in accordance with the state strategy for energy saving and its formation at the regional level. Implementing an energy saving strategy helps the company to avoid risks and gain a competitive advantage over other companies that present their products or services on the market. This strategy should be the basis for effective management of energy saving processes in the long-term energy, economic and innovation policy of the enterprise.

The criteria presented in Figure 2 should be considered comprehensively, because alone can not be an absolute indicator of the effectiveness of the implementation of energy saving measures and organizational and economic concept in general.

Assume that the energy saving potential has a linear relationship, so the list of services can be predicted several years in advance. The transition to alternative and renewable energy sources gives the company the opportunity to abandon the use of electricity, for which there is no fixed price and gain full independence from monopoly companies and external conditions.

Independence from energy makes it possible not only to increase profitability, but also to reduce operational and financial risks. The result of the implementation of the organizational and economic concept is an increase in energy saving in enterprises, which leads to increased profitability. The economic mechanism consists of the following elements:

- reduction of specific energy consumption of employees of the enterprise;

- stimulating employees of the enterprise to save energy resources;

- reduction of costs and tariffs for services provided;

- calculation of resource savings due to the introduction of energy saving measures or a set of measures.

One of the main areas of improvement of the organizational and economic concept is the production and household spheres of economic activity of the enterprise, development and creation of energy saving 
measures at the state and regional level; division of energy saving management into categories of subject and object; characteristics of the principles and criteria for evaluating the effectiveness of the mechanism; audit of the enterprise and determination of energy saving potential; monitoring the condition and taking into account the factors of influence of external and internal environments.

The organizational concept covers the following main components: economic and energy inspection of the object, formation and implementation of energy saving measures and its monitoring. The implementation of energy saving should be carried out in accordance with the state strategy for energy saving and its formation at the regional level [6].

The implementation of planned energy saving measures requires the use of technical, economic, organizational, legal and other methods. The company should ensure monitoring, measurement and analysis of energy efficiency indicators, on the basis of which conclusions are made about the effectiveness of the chosen strategy, if necessary, revise the overall development strategy, energy policy. Achieving the system of goals within the chosen energy saving strategy will ensure the most efficient use of energy resources to prevent internal and external threats and promote the stable operation of the production enterprise, which are the priority areas of its economic security [1]. Methodical bases of the organizational and economic concept of maintenance of energy efficiency of the enterprise are generalized in figure 3.

Organizational and economic concept of energy efficiency of the enterprise

provides:

- analysis of the financial

condition of the enterprise;

- study of the actual level of

energy consumption;

- study of basic and auxiliary

production processes;

- calculation of the level of

energy consumption of

products;

- formation of priority

directions of research of energy

saving potential;

- identification of places of

energy loss;

- research of energy waste

potential;

- determination of ways of

redistribution of utilized

energy;

- compilation of energy

balances

provides:

- formation of energy

management service;

- analysis of the dynamics of

energy consumption;

- determination of energy

intensity levels of products;

-control over compliance with

energy saving measures.

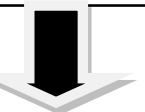

Economic and energy

survey of the enterprise and definition of potential

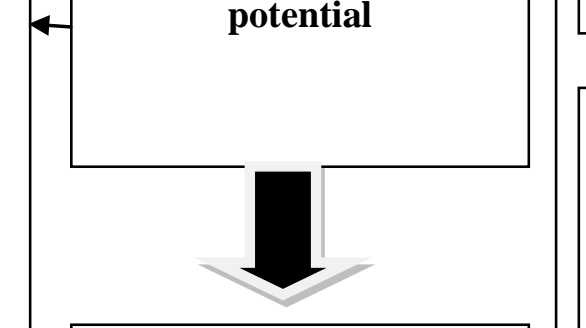

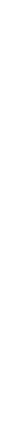
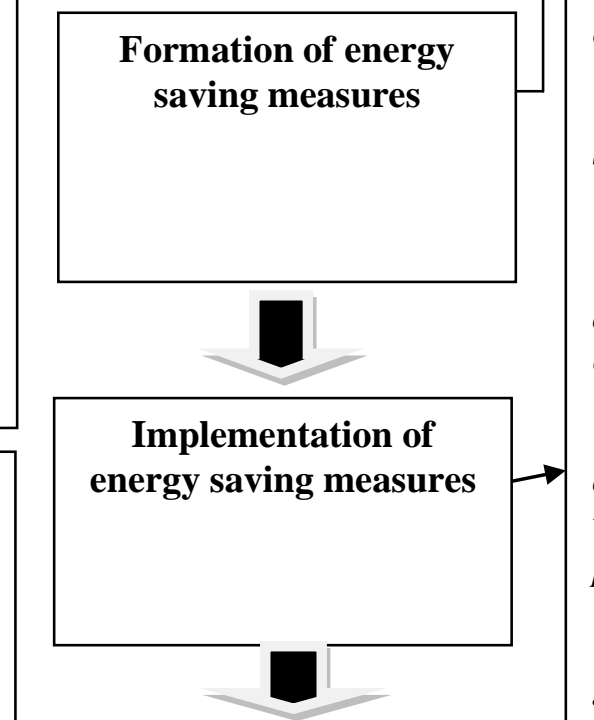

Condition monitoring includes:

-economic measures; -organizational activities;

-technical measures;

-technological measures.

requires:

-elimination of direct costs;

- introduction of

organizational mechanisms

to increase energy efficiency

of production;

- application of measures to stimulate responsibility for

irrational use of resources;

- transfer of production to alternative and renewable energy sources;

- use of the potential of solid and liquid production wastes for energy production;

- utilization of heat of flue gases, air, condensate and other material carriers of energy

Fig. 3. Conceptual model of organizational and economic concept of energy efficiency of the enterprise

Source: developed by the authors on the basis of [7] 
The main result of the implementation of organizational and economic concept in enterprises is a combination of a set of elements that reduce energy costs per unit of output and increase the efficiency of the enterprise.

The main tasks of the economic mechanism of energy saving are motivation to rational use of energy, saving of fuel and energy resources, introduction into production of energy-efficient technologies and processes, equipment and materials.

The main source of funding for energy saving measures is the State Energy Saving Fund, own and borrowed funds of enterprises, institutions and organizations.

The sources of formation of the State Energy Saving Fund are:

- funds received for the issuance by the central body of executive power, which implements state policy in the field of efficient use of fuel and energy resources, permit documents;

- voluntary contributions of enterprises, institutions, organizations and citizens.

Basically, all funds from the fund are used to finance energy saving measures, for the rational use and saving of fuel and energy resources, research, design work, granting credit benefits and subsidies for the development and implementation of energy saving.

Funds are also allocated from the fund for the development of unconventional energy, production of alternative fuels, state examinations, retraining of personnel, development of energy standards, norms and standards, participation in equipping enterprises with equipment, equipment.

Economic measures to ensure energy conservation are based on the principles of mutual economic responsibility and include:

a) compensatory payments and compensation of losses to consumers of fuel and energy resources in case of non-fulfillment of contractual conditions of fuel by energy supply institutions;

b) compensation of losses to suppliers of fuel and energy resources in case of non-fulfillment of contractual conditions by consumers;

c) the obligation of the energy supplier to obligatorily accept the consumer's applications for connection of loading and increase of energy consumption with the right of the supplier to establish contractual prices for the connected capacity and the excess energy used and used;

d) the right of the energy consumer to receive compensatory payments from the supplier in case of compulsory restriction of the power actually used by the consumer.

Stimulation of energy saving is carried out by:

a) providing tax benefits to enterprises - manufacturers of energy-saving equipment, machinery and materials, measuring instruments, control and management of fuel and energy resources, manufacturers of equipment for the use of energy sources;

b) providing tax benefits to enterprises that use equipment that works on non-traditional and renewable energy sources, alternative fuels;

c) priority lending of measures to ensure the rational use and saving of fuel and energy resources.

Energy saving measures - a complex process that affects the intermediate and intermediate results of economic activity of the enterprise. For more efficient operation of the energy saving mechanism, it is necessary to evaluate their implementation efficiency.

The results of the implementation of energy saving measures will be expressed in various effects, in particular economic, social and environmental:

- the economic effect arises as a result of the received economy of energy resources that reduces prime cost of agricultural production;

- the social effect is manifested in the improvement of working conditions of workers. However, as a result of the introduction of energy-saving equipment and technology, there may be a negative social effect as a result of reduction (dismissal) of employees.

- ecological effect is obtained as a result of reduction of contaminated soils and other harmful emissions into the environment. This effect can be estimated by determining the amount for which losses are prevented due to the implementation of energy saving measures.

Costs for the implementation of energy saving measures are formed from the fixed costs of production and costs of energy management. Fixed costs include the cost of energy and other resources; to spend on operation, including the cost of repairs, wages and deductions from it; other costs provided by regulatory documents on the calculation of cost; depreciation deductions.

The effectiveness of the implementation of the mechanism as a result depends on the management of energy saving in the enterprise as a whole. The creation and construction of an effective system of energysaving measures and programs will be perfect if employees take seriously the saving and rational use of fuel 
and energy resources, energy and, in general, reduce the negative impact on the environment, which can have a negative impact on the environment.

Management of energy potential of enterprises is based on energy management, which consists of voluntary, proactive and effective actions of economic entities that are directly interested in the effective implementation of energy saving measures in production processes.

Conclusions. The studied basic principles and components of the organizational and economic concept of energy saving will allow to form a motivational mechanism of energy saving at the enterprise. Implementation of the developed methodological bases of the concept of energy saving at the enterprises of Ukraine will allow to increase energy independence of the country, to strengthen competitive positions and to adapt to the European standards.

\section{REFERENCES:}

1. Barannik, V.O. (2012), "Enerhetychna bezpeka derzhavy: analiz stanovlennia suchasnoi paradyhmy” Visnyk Skhidnoukrainskoho natsionalnoho universytetu im. V. I. Dalia, vol. 1, pp. 145 - 154. Access mode: http://www.nbuv.gov.ua/portal/soc gum/vsunu/2012 1 2/Baranni.pdf

2. Bevz, V.V. (2011), "Rozvytok mekhanizmu enerhozberezhennia na pidpryiemstvakh kharchovoi promyslovosti”, Vcheni zapysky, vol 13., pp. 169 - 173.

3. Vovk, Yu. (2011), “Orhanizatsiino-ekonomichnyi mekhanizm upravlinnia ratsionalnym vykorystanniam resursiv”, Sotsialno-ekonomichni problemy i derzhava, vol. 1 (40), pp. 38 - 56. Access mode: http://sepd.tntu.edu.ua/images/stories /pdf/2011/11vyyrvr.pdf.

4. Dzhedzhula, V.V. (2013), "Formuvannia orhanizatsiino-ekonomichnoho mekhanizmu pidvyshchennia enerhoefektyvnosti promyslovykh pidpryiemstv”, Ekonomichnyi analiz, vol. 12, pp. 116 118.

5. Dokunina, K.I. (2012), “Teoretychni aspekty formuvannia ekonomichnoho mekhanizmu enerhozberezhennia”, Komunalne hospodarstvo mist, vol. 106, pp. 341 - 350.

6. Enerhetychna stratehiia Ukrainy na period do 2030 roku (2013) "Vidomosti Ministerstva palyva ta enerhetyky Ukrainy” https://zakon.rada.gov.ua/laws/main/n0002120-13

7. Ippolitova, I.Ia. and Sorokotiazhenko, K.S. (2015), "Formuvannia orhanizatsiino-ekonomichnoho mekhanizmu enerhozberezhennia na pidpryiemstvi”, Hlobalni ta natsionalni problemy ekonomiky, vol 8, pp. $406-411$.

8. Kyprianou, I. Serghides, D.K. Varo, A. Gouveia, J.P. Kopeva, D. and Murauskaite, L. (2019), "Energy poverty policies and measures in 5 EU countries: A comparative study", Energy and Buildings, vol. 196, pp. 46 - 60. https://doi.org/10.1016/j.enbuild.2019.05.003

9. Mykhailenko, I. D. (2006), "Polityka enerhozberezhennia, potentsialni mozhlyvosti enerhozberezhennia v Ukraini”, Enerhosberezhenye, vol. 1, pp. 3 - 8.

10. Nemish, P.D. (2013), "Sutnist, otsinka ta napriamy pidvyshchennia efektyvnosti mekhanizmu enerhozberezhennia APK”, Innovatsiina ekonomika, vol 7 (45), pp. 46-53. Ukraine.

11. Zhovtianskiy, V.A. (2016), Stratehiia enerhozberezhennia v Ukraini, [Akademperiodyka], Kyiv,

12. Zhovtianskiy, V.A. Kulyka, M.M. Stohniiy, B.S. (2014), Stratehiia enerhozberezhennia v Ukraini, [Zahalni zasady enerhozberezhennia] Kyiv, Ukraine.

13. Serdiuk, T.V. (2005), Orhanizatsiino-ekonomichnyi mekhanizm enerhozberezhennia v promyslovosti: monohr, [UNIVERSUM],Vinnytsia, Ukraine.

14. Chystov, Yu.I. (2010), "Sutnist mekhanizmu enerhozberezhennia ta yoho bahatohranna pryroda", Visnyk Khmelnytskoho natsionalnoho universytetu. Ekonomichni nauky, vol 5, pp. 341 - 344.

15. Shivakumar, A. Dobbins, A. Shivakumar, A. Fahl, U., Singh A. "Drivers of renewable energy deployment in the EU: An analysis of past trends and projections", Energy Strategy Reviews, vol. 26, pp. 345 - 368. https://doi.org/10.1016/j.esr.2019.100402

УДК 338.012

JEL F 02

Биба Володимир Васильович, кандидат технічних наук, доцент. Міняйленко Інна Валентинівна, кандидат економічних наук, доцент. Національний університет «Полтавська політехніка імені Юрія Кондратюка». Методичні основи формування організаційно-економічної концепції енергозбереження. Головним принципом економіки України $\epsilon$ побудова 
енергоефективного суспільства, впровадження енергозберігаючих програм і проектів. Досліджено основні підходи вітчизняних та зарубіжних учених щодо трактування організаційно-економічного механізму енергозбереження як поєднання й упровадження цілей, імпульсів та управлінських дій, спрямованих на зниження витрат на енергоресурси. Визначено основні завдання концепції, метою яких є зменшення енергетичної залежності на основі науково обгрунтованих методів та інструментів. Сформовано принципи економічності, відповідальності, цілісності, комплексності, що покладено в основу розробленої методики. Узагальнено критерії оцінювання ефективності організаційноекономічної концепції енергозбереження, що грунтуються на збільшенні його потенціалу в процесі використання альтернативної енергетики й посиленні мотивації щодо зниження енергоємності виробництва. Побудовано методику формування концепції енергозбереження та розкрито сутність кожного етапу. Визначено джерела фінансування впровадження енергозберігаючих проектів. Розкрито мотиваційні заходи й методи стимулювання впровадження енергозберігаючих заходів. Зазначено отримані ефекти від реалізації концепції енергозбереження.

Ключові слова: енергозбереження, механізм, принципи, критерії, мотивація, стимули.

UDC 338.012

JEL F 02

Byba Volodymyr, PhD (Technical sciences), Assoc. Professor. Miniailenko Inna, PhD (Economics), Assoc. Professor. Methodical Foundations of Organizational and Economic Concept Formation of Energy Saving. The main principle of Ukraine's economy is to build an energy-efficient society, implement energy-saving programs and projects. The main approaches by domestic and foreign scientists to the interpretation of the organizational and economic mechanism of energy saving are studied. The main tasks of the concept are defined. The principles of economy, responsibility, integrity, complexity are formed, which is the basis of the developed methodology. The criteria for evaluating the effectiveness of the organizational and economic concept of energy saving are summarized. The method of forming the concept of energy saving is proposed and the essence of each stage is revealed. Sources of financing for the implementation of energy saving projects have been identified. Motivational measures and methods of stimulating the introduction of energy saving measures are revealed. The obtained effects from the implementation of the concept of energy saving are indicated.

Keywords: energy saving, mechanism, principles, criteria, motivation, stimuli. 